\title{
Total Synthesis of Manzamine A and Related Alkaloids
}
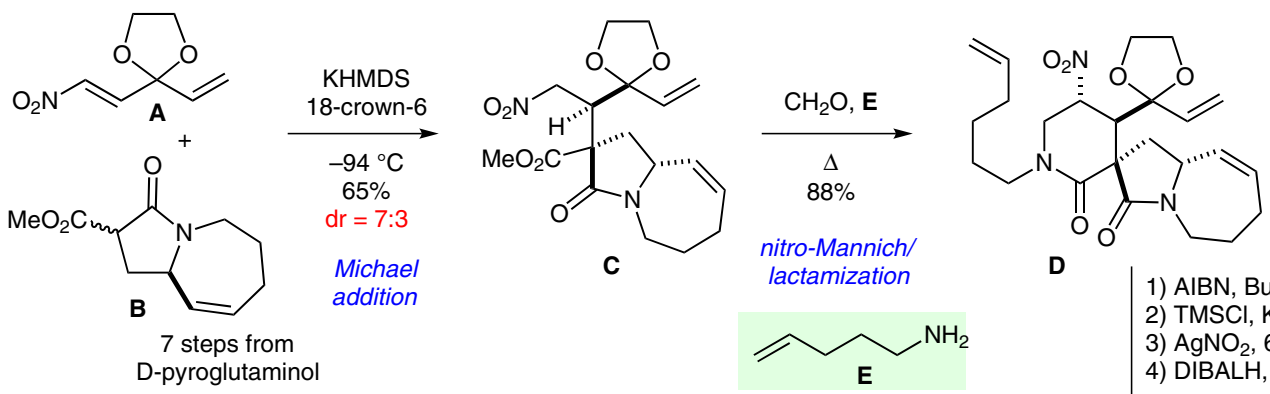

Synthesis of Natural

Products and

Potential Drugs

\section{Key words}

nitro-Mannich reaction

ring-closing metathesis

Michael addition

alkaloids

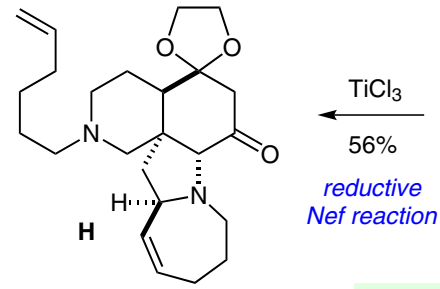<smiles>C=CCCCCN1CCC2C(C[C@@H]([N+](=O)[O-])CC23OCCO3)C1</smiles>

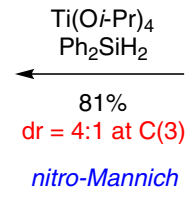<smiles>CC1C=CCCCN1C</smiles>

nitro-Mannich

D

2) $\mathrm{J}, \mathrm{CeCl}_{3}$ then $\mathrm{HCl}, 91 \%$

3) TMSOTf, $\mathrm{Et}_{3} \mathrm{~N}, 72 \%$

4) $\mathrm{K}, \mathrm{KHMDS}, 90 \%$

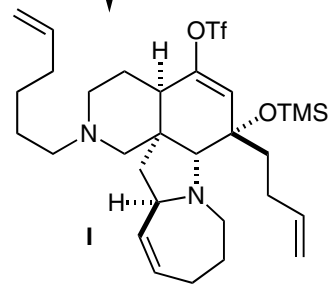<smiles>C=CCC[Mg]Br</smiles>

Angew. Chem. Int. Ed. 1996, 35, 1515.<smiles>[Y16]c1ccc(Cl)cn1</smiles>

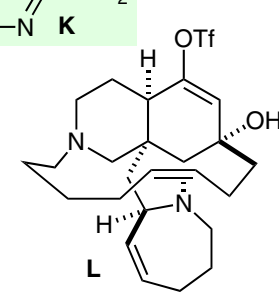<smiles>O=P(O)(Cl)(Cl)(Cl)CP</smiles><smiles>CCCCc1nccc2c1[nH]c1ccccc12</smiles>

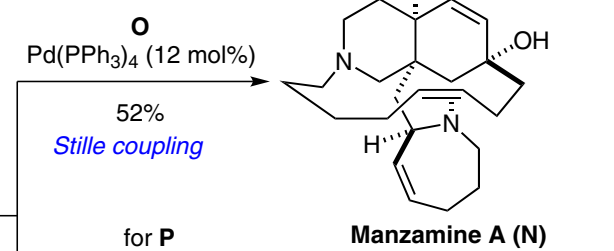
$\mathrm{Pd}(\mathrm{OAc})_{2}(18 \mathrm{~mol} \%)$ $\mathrm{PPh}_{3}, \mathrm{CO}, \mathrm{MeOH}$ $78 \%$ for $\mathbf{Q}$ $\mathrm{Pd}\left(\mathrm{PPh}_{3}\right)_{4}(10 \mathrm{~mol} \%)$ $\mathrm{CO}, \mathrm{LiCl}, \mathrm{Bu}_{3} \mathrm{SnH}$ $58 \%$ carbonylation 1) $\mathrm{AIBN}, \mathrm{Bu}_{3} \mathrm{SnH}, 77 \%$ 2) $\mathrm{TMSCl}, \mathrm{KI}, 81 \%$ 3) $\mathrm{AgNO}_{2}, 63 \%$ 4) DIBALH, $74 \%$

DIBALH, 82\%<smiles>C=CCCCCN1CCC(C2(CC[N+](=O)[O-])C[C@H]3C=CCCCN3C2=O)[C@@]2(CCOC2)C1</smiles>

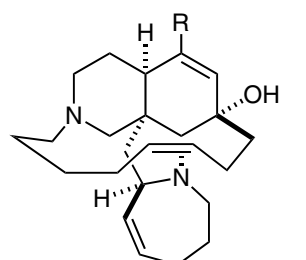

$P \mathrm{R}=\mathrm{CO}_{2} \mathrm{Me}$ (Methyl Ircinate) $\mathrm{QR}=\mathrm{CH}_{2} \mathrm{OH}$ (Ircinol A) R R $=\mathrm{CHO}$ (Ircinal A)

Significance: Manzamine $A(\mathbf{N})$ is a highly structurally complex alkaloid with a wide range of biological activities. The total synthesis reported is the shortest to date, accessing manzamine $A(\mathbf{N})$ in 20 linear steps from commercially available starting materials. The key feature of the synthesis is the use of nitro groups as handles to construct two rings of the manzamine core by nitro-Mannich reactions.

SYNFACTS Contributors: Erick M. Carreira, Stefan Diethelm Synfacts 2013, 9(1), $0017 \quad$ Published online: 17.12.2012 DOl: 10.1055/s-0032-1317852; Reg-No.: C02412SF
Comment: The total synthesis of manzamine A $(\mathbf{N})$ starts with a Michael addition onto nitroolefin A. A series of two nitro-Mannich reactions delivers $\mathbf{I}$, which undergoes ring-closing metathesis to construct the 13-membered ring incorporating a Zdouble bond. Palladium-catalyzed coupling reactions on vinyl triflate $\mathbf{L}$ produce manzamine $\mathrm{A}(\mathbf{N})$ or the related alkaloids $\mathbf{P}-\mathbf{Q}$, alternatively. 